\title{
Spectrum of Cervical Cytological Lesions in Premenopausal and Postmenopausal Women
}

\author{
Vaishali Baburao Nagose*, Nirvana Rasaily Halder, Shruthi Amit Deshpande, \\ Shivanand Shriram Rathod and Varsha Ashok Jadhav
}

Department of Pathology, Mamata Medical College, Rotary Nagar, Khammam, Telangana. India

\section{ABSTRACT}

Background: Screening with Pap smear initially targets women with higher prevalence of high grade precancerous cervical lesions [Cervical Intraepithelial Neoplasia 2/3 (CIN2/CIN3)] - women mostly in their third and fourth decade. But different conditions affect uterine cervix, including non neoplastic \& neoplastic diseases, at different age. Thus, the Pap smears findings should vary in premenopausal \& post menopausal groups.

Methods: A prospective study of two years was conducted to screen Pap smears in women who were categorised as premenopausal age group $<46$ years \& postmenopausal $\geq 46$ years.

Result: A total of 6647 cases were analysed within age ranging from 18 to 85 years. 5369 (80.77\%) patients were in premenopausal \& 1278 $(19.23 \%)$ in postmenopausal age group. Premenopausal group showed interpretation as "Negative for Intraepithelial Lesion or Malignancy" (NILM) in $97.56 \%$. Here, two of the three cases of Squamous Cell Carcinoma (SCC) were of $<40$ years. Postmenopausal age group showed maximum cases of Atypical Squamous Cells of Undetermined Significance (ASCUS), Low Grade Squamous Intraepithelial Lesion (LSIL) \& SCC. Maximum cases of High-Grade Squamous Intraepithelial Lesion (HSIL) belonged to $>60$ years.

Conclusion: It is suggested that the Pap screening should not be ceased, but be continued beyond 60 years of age. In premenopausal age, along with SIL, the possibility of malignancy should not be neglected \& infections should also be paid more attention. Thus, irrespective of the age of female after $30 \mathrm{yrs}$, it is highly recommended for them to undergo PAP screening.

Keywords: Pap Smear, Premenopausal, Postmenopausal, ASCUS, HSIL, SCC.

\section{Introduction:}

Cervix, the gatekeeper of the uterus, gets its name from the Latin word meaning "neck" due to its role as the narrow connection between the larger body of the uterus above \& the vagina below. Various conditions can affect uterine cervix, including non neoplastic \& neoplastic diseases. The incidence of these varies according to the different age groups.

Cervical inflammatory lesions are very common in sexually active females all over the world; with non specific cervicitis, the most common of them, found commonly in third decade, also on histopathalogy. ${ }^{[1]}$ Otherwise it can be said to occur rarely before menarche or after menopause. ${ }^{[2]}$ The etiology is variable and is of importance because it may lead to considerable morbidity as endometritis, salphingitis, pelvic inflammatory disease, chorioamnionitis and also it may have a role in the initiation or promotion of cervical neoplasia. ${ }^{[3]}$

The most important neoplastic condition - carcinoma cervix - the second most common carcinoma in females worldwide - has peak age of incidence at 47 years world over \&55-59 years in India. It has a long latent phase during which it can be detected as identifiable and treatable premalignant lesions which precede the invasive disease by upto 10 years. ${ }^{[4]}$ The transformation zone is the most common site of initiation of the neoplastic process in it, ${ }^{[5,[6]}$ which is easily amenable to screening by PAP smear. The success story of the Pap smear, in bringing down the incidence of invasive cervical carcinoma is already known. Also it has caused a shift toward earlier stages at the time of diagnosis which has brought down the mortality. This reduction in the incidence and mortality of invasive cervical cancer is dramatic \& observed worldwide. ${ }^{[7]}$ The Bethesda System (TBS) for reporting cervical cytology has been used for almost three decades now guiding the proper management by clinicians based on the cytological interpretation clearly giving the terms for premalignant $\&$ malignant lesions.

Pap smears findings should thus vary in premenopausal \& postmenopausal groups in terms of infections, premalignant \& malignant lesions, as sought after in this study.

\section{Materials and Methods:}

This study was conducted in the Department of Pathology, at a Medical College in South India; over a period of two 
years, from July 2015 to June 2017. A total of 6647 cases were selected who were above 18 years and sexually active for $>3$ years.

Relevant history, presenting complaints (like discharge per vaginum, bleeding per vaginum, pain in lower abdomen, backache) and examination findings including per speculum findings were entered in a proforma.

On the day of procuring Pap smear care was taken that no local douche, antiseptic cream and no local internal examination was done. The patient was placed in dorsal lithotomy position. After proper positioning, gently a sterile Cusco's bivalve speculum was introduced through vagina and cervix was visualized. The longer projection of the Ayre's spatula was placed in the cervix near squamo-columnar junction and rotated through $360^{\circ}$. The cellular material thus obtained was quickly, but gently smeared on a clean glass slide. The glass slide was then immediately put into the Coplin jar containing 95\% ethyl alcohol as a fixative. The prepared smears were then stained according to Papanicolaou's technique. The cytological interpretation of the smears was made according to The Bethesda System 2014.

For analysis purpose they were subdivided into premenopausal $(<46$ yrs) \& postmenopausal $(\geq 46$ yrs or history of attaining menopause) groups. ${ }^{[8]}$

\section{Result}

Total 6647 patients fulfilling the inclusion criteria in the above mentioned period with ages ranging from 18 to 85 years were analysed. Out of them, $5369(80.77 \%)$ patients were in premenopausal \& $1278(19.23 \%)$ in postmenopausal age group. The most common presenting complaint was discharge per vaginum, present in 5296 (77.68\%) patients. Post menopausal bleeding was the chief complaint in 14 patients $(0.21 \%)$. Only $5(0.08 \%)$ patients presented with post-coital bleeding. Most common per speculum finding was white discharge at external os in $5127(77.13 \%)$ patients. Ulcerative or fungating growth was observed in only 5 patients $(0.08 \%)$.

The categorization of all the patients according to The Bethesda System 2014 is shown in Table 1. Total 180
$(2.71 \%)$ smears were unsatisfactory. Various organisms were seen, some common ones like Bacterial vaginosis, Trichomonas vaginalis (Figure 1) and Candida, and few less common organisms like Herpes Simplex Virus. Epithelial abnormalities included - Atypical squamous cells (ASC) - of Undetermined Significance (ASCUS) \& cannot exclude HSIL (ASC-H); Squamous Intraepithelial Lesion (SIL) - Low-grade (LSIL) \& High-grade (HSIL); Squamous cell carcinoma (SCC); Atypical Glandular cells of Undetermined Significance (AGUS) \& Adenocarcinoma.

Premenopausal Age Group: Of the smears obtained from 5369 premenopausal patients of this study, 96 $(1.79 \%)$ were unsatisfactory. The major finding in them was obscuration of the cellular details due to either dense acute inflammatory infiltrate or blood. The majority of the smears (5238 - 97.56\% of premenopausal age group) belonged to NILM category, of them the maximum (2418 - 46.16\% of this age group) had interpretation as 'Inflammatory smear without underlying pathology'. Most common interpretation in organism subcategory was 'Shift in flora suggestive of bacterial vaginosis' (1428 - 26.6\% of premenopausal age group). Only $0.65 \%$ of patients showed epithelial abnormalities. In this group, most cases of HSIL (six out of 11) fell between $30-39$ years age, this decade was also the second most common affected age group for it overall. Two of the 3 cases of SCC of this group were $<40$ years of age. (Table2) One case each of Adenocarcinoma \& ASC-H were found.

Postmenopausal Age Group: Out of the 1278 post menopausal cases, 84 (6.57\%) smears were unsatisfactory, main cause being scant cellularity. 1149 (89.91\%) were reported as NILM \& $3.44 \%$ (44) showed epithelial abnormalities. Total $18.31 \%$ women of this age group showed 'Shift in flora suggestive of bacterial vaginosis', which was the largest of organism subcategories. Maximum patients with epithelial abnormality belonged to ASCUS subcategory -18 smears, followed by 11 belonging to HSIL. Maximum cases of HSIL (7) were in $\geq 60$ years of age (Table 2).

Table 1: General Categorization of PAP smears according to The Bethesda System 2014.

\begin{tabular}{|l|c|c|c|}
\hline Category & $\begin{array}{c}\text { PremenopausalNo } \\
\text { of cases (\% of } \\
\text { Premeno-pausal } \\
\text { group) }\end{array}$ & $\begin{array}{c}\text { PostmenopausalNo } \\
\text { of cases (\% of } \\
\text { Postmenopausal } \\
\text { group) }\end{array}$ & $\begin{array}{c}\text { Overall No of } \\
\text { cases (\%) }\end{array}$ \\
\hline Unsatisfactory & $96(1.79 \%)$ & $84(6.57 \%)$ & $180(2.71 \%)$ \\
\hline NILM & $5238(97.56 \%)$ & $1149(89.91 \%)$ & $6387(96.09 \%)$ \\
\hline
\end{tabular}




\begin{tabular}{|c|c|c|c|c|c|c|}
\hline \multicolumn{4}{|c|}{ Category } & \multirow{2}{*}{$\begin{array}{c}\begin{array}{c}\text { PremenopausalNo } \\
\text { of cases (\% of } \\
\text { Premeno-pausal } \\
\text { group) }\end{array} \\
645 \\
\end{array}$} & \multirow{2}{*}{$\begin{array}{c}\text { PostmenopausalNo } \\
\text { of cases (\% of } \\
\text { Postmenopausal } \\
\text { group) }\end{array}$} & \multirow{2}{*}{$\begin{array}{c}\begin{array}{c}\text { Overall No of } \\
\text { cases }(\%)\end{array} \\
777 \\
\end{array}$} \\
\hline \multirow{10}{*}{ NILM } & \multicolumn{3}{|l|}{ Normal } & & & \\
\hline & \multicolumn{3}{|c|}{\begin{tabular}{|l|} 
Inflammatory smear without underlying pathology \\
\end{tabular}} & 2418 & 437 & 2855 \\
\hline & \multirow{3}{*}{$\begin{array}{l}\text { Non-Neoplastic } \\
\text { Findings }\end{array}$} & \multicolumn{2}{|c|}{ Non-neoplastic cellular variations (Atrophy) } & -- & 232 & 232 \\
\hline & & $\begin{array}{l}\text { Reactive } \\
\text { cellular changes } \\
\text { associated with: }\end{array}$ & Inflammation & 118 & 46 & 164 \\
\hline & & & $\begin{array}{l}\text { Lymphocytic (follicular) } \\
\text { cervicitis }\end{array}$ & 0 & 2 & 2 \\
\hline & \multirow{5}{*}{ Organisms } & \multicolumn{2}{|c|}{ Trichomonas vaginalis } & 229 & 23 & 252 \\
\hline & & \multicolumn{2}{|c|}{$\begin{array}{l}\text { Fungal organisms morphologically consistent } \\
\text { with Candida spp. }\end{array}$} & 248 & 40 & 288 \\
\hline & & \multicolumn{2}{|c|}{ Shift in flora suggestive of Bacterial Vaginosis } & 1428 & 234 & 1662 \\
\hline & & \multicolumn{2}{|c|}{$\begin{array}{l}\text { Cellular changes consistent with Herpes Simplex } \\
\text { Virus }\end{array}$} & 1 & 0 & 1 \\
\hline & & \multicolumn{2}{|c|}{ Cytolysis due to Lactobacilli } & 151 & 3 & 154 \\
\hline \multicolumn{4}{|c|}{ Other-Endometrial cells (in a woman $>45$ years of age) } & Not applicable & $1(\mathrm{NILM})(0.08 \%)$ & $1(0.02 \%)$ \\
\hline \multicolumn{4}{|c|}{ Epithelial cell abnormality (ECA) } & $35(0.65 \%)$ & $44(3.44 \%)$ & $79(1.19 \%)$ \\
\hline \multirow{7}{*}{ ECA } & \multirow[t]{5}{*}{$\begin{array}{l}\text { SQUAMOUS } \\
\text { CELL }\end{array}$} & \multirow[t]{2}{*}{$\begin{array}{l}\text { Atypical } \\
\text { squamous cells }\end{array}$} & ASC-US & 11 & 18 & 29 \\
\hline & & & ASC-H & 1 & 0 & 1 \\
\hline & & & LSIL & 7 & 8 & 15 \\
\hline & & & HSIL & 11 & 11 & 22 \\
\hline & & & Squamous cell carcinoma & 3 & 6 & 9 \\
\hline & \multirow[t]{2}{*}{$\begin{array}{l}\text { GLANDULAR } \\
\text { CELL }\end{array}$} & & AGUS & 1 & 1 & 2 \\
\hline & & Adenocarcinoma & & 1 & 0 & 1 \\
\hline \multicolumn{4}{|l|}{ Total } & 5369 & 1278 & 6647 \\
\hline
\end{tabular}

NILM: negative for intraepithelial lesion malignancy.; ASC-US : Atypical squamous cell of Undetermined Significance.; ASC-H: Atypical squamous cell cannot exclude HSIL.; LSIL: Low-grade Squamous Intraepithelial Lesion.; HSIL: High-grade Squamous Intraepithelial Lesion.; SCC: Squamous cell carcinoma.; AGUS: Atypical Glandular cells of Undetermined Significance.

Table 2: Age wise distribution of Epithelial Abnormalities.

\begin{tabular}{|c|c|c|c|c|c|c|c|c|}
\hline \multicolumn{3}{|c|}{ Epithelial cell abnormality } & \multicolumn{5}{|c|}{ Age groups (years) } & \multirow{3}{*}{\begin{tabular}{|r|} 
Tota \\
29
\end{tabular}} \\
\hline & & & \multirow{2}{*}{$\begin{array}{r}<30 \\
2\end{array}$} & \multirow{2}{*}{$\begin{array}{c}30-39 \\
6\end{array}$} & \multirow{2}{*}{$\begin{array}{c}40-49 \\
7 \\
\end{array}$} & \multirow{2}{*}{$\begin{array}{c}50-59 \\
11 \\
\end{array}$} & \multirow{2}{*}{$\begin{array}{c}>60 \\
3\end{array}$} & \\
\hline \multirow{5}{*}{$\begin{array}{l}\text { SQUAMOUS } \\
\text { CELL }\end{array}$} & \multirow{2}{*}{$\begin{array}{l}\text { Atypical sq } \\
\text { cells }\end{array}$} & ASC-US & & & & & & \\
\hline & & ASC-H & 0 & 1 & 0 & 0 & 0 & 1 \\
\hline & \multicolumn{2}{|c|}{ LSIL } & 1 & 2 & 8 & 2 & 2 & 15 \\
\hline & \multicolumn{2}{|c|}{ HSIL } & 2 & 6 & 4 & 3 & 7 & 22 \\
\hline & \multicolumn{2}{|c|}{ Squamous cell ca } & 0 & 2 & 5 & 2 & 0 & 9 \\
\hline \multirow{2}{*}{$\begin{array}{l}\text { GLANDULAR } \\
\text { CELL }\end{array}$} & \multicolumn{2}{|c|}{ AGUS } & 0 & 0 & 1 & 1 & 0 & 2 \\
\hline & \multicolumn{2}{|c|}{ Adenocarcinoma } & 0 & 0 & 1 & 0 & 0 & 1 \\
\hline \multicolumn{3}{|l|}{ Total } & 5 & 17 & 26 & 19 & 12 & 79 \\
\hline
\end{tabular}

ASC-US : Atypical squamous cell of Undetermined Significance.; ASC-H: Atypical squamous cell cannot exclude HSIL.; LSIL: Low-grade Squamous Intraepithelial Lesion.; HSIL: High-grade Squamous Intraepithelial Lesion.; SCC: Squamous cell carcinoma.; AGUS: Atypical Glandular cells of Undetermined Significance. 
Table 3: Comparison of Recent Studies of PAP Smears in South India (2015-17).

\begin{tabular}{|c|c|c|c|c|c|c|c|}
\hline \multirow{2}{*}{$\begin{array}{l}\text { Sr } \\
\text { no }\end{array}$} & \multirow{2}{*}{ Authors } & \multirow{2}{*}{$\begin{array}{l}\text { No of } \\
\text { cases }\end{array}$} & \multirow{2}{*}{ Unsatisfactory } & \multicolumn{2}{|c|}{ NILM } & \multirow{2}{*}{ Other } & \multirow{2}{*}{$\begin{array}{l}\text { Epithelial } \\
\text { abnormality }\end{array}$} \\
\hline & & & & Normal & Inflammatory & & \\
\hline 1 & Deepthi (2017) ${ }^{[10]}$ & 1000 & $2.5 \%$ & $9 \%$ & $70.6 \%$ & - & $17.9 \%$ \\
\hline 2 & Shashidhar (2017) ${ }^{[11]}$ & 308 & $2.27 \%(7)$ & $49.03 \%(151)$ & $45.78 \%(141)$ & - & $2.92 \%(9)$ \\
\hline 3 & Pushpalata (2017) ${ }^{[12]}$ & 417 & - & - & $91.61 \%(382)$ & - & $8.39 \%(35)$ \\
\hline 4 & Shardamani $(2017)^{[13]}$ & 300 & $6.33 \%(19)$ & $4.33 \%(13)$ & $77.33 \%(232)$ & - & $12 \%(36)$ \\
\hline 5 & Ali $(2017)^{[14]}$ & 240 & $5 \%(12)$ & $5.4 \%(13)$ & $77.1 \%(185)$ & - & $12.5 \%(30)$ \\
\hline 6 & R Sujatha (2017) ${ }^{[15]}$ & 500 & $1.4 \%(7)$ & $46.20 \%(231)$ & $45.4 \%(227)$ & - & $2.8 \%(24)$ \\
\hline 7 & Umarani $(2016)^{[16]}$ & 1418 & $9.3 \%(132)$ & - & $82.09 \%(1164)$ & - & $8.61 \%(122)$ \\
\hline 8 & P Sujatha (2016) $)^{[17]}$ & 500 & $0.8 \%(4)$ & $2.6 \%(13)$ & $88.6 \%(443)$ & - & $8 \%(40)$ \\
\hline 9 & Geethu (2016) $)^{[18]}$ & 2028 & $2.71 \%(55)$ & $56.81 \%(1152)$ & $38.07 \%(772)$ & - & $2.42 \%(49)$ \\
\hline 10 & K Chaithanya $(2016)^{[19]}$ & 5559 & $0.72 \%(40)$ & $17.68 \%(983)$ & $79.39 \%(4413)$ & - & $2.21 \%(123)$ \\
\hline 11 & Atla (2015) ${ }^{[20]}$ & 380 & $6.32 \%(24)$ & $2.63 \%(10)$ & $65.26 \%(248)$ & - & $25.79 \%(98)$ \\
\hline 12 & Present study & 6647 & $2.71 \%(180)$ & $11.69 \%(777)$ & $84.5 \%(5617)$ & $0.02 \%(1)$ & $1.19 \%(79)$ \\
\hline
\end{tabular}

NILM: Negative for Intraepithelial Lesion Malignancy.

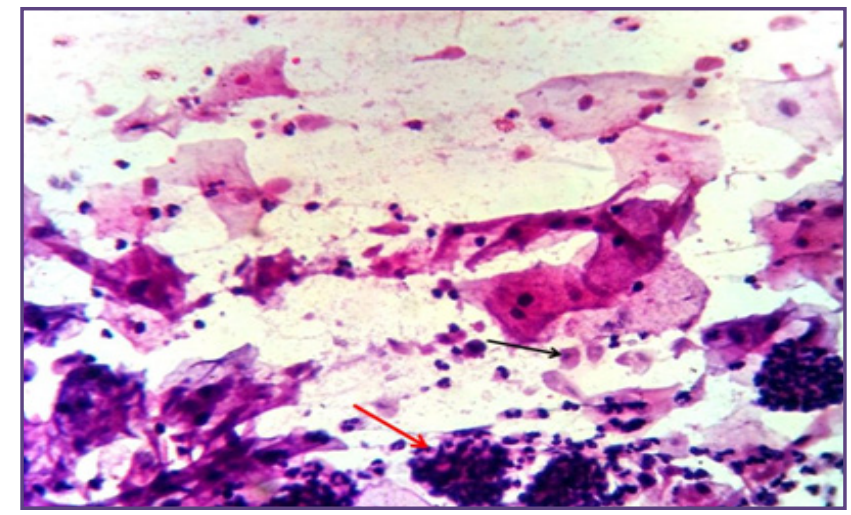

Fig. 1: Trichomonas vaginalis: Pear shaped organism with eccentrically located nucleus (black arrow) along with cannon balls (red arrow). (PAP stain, 400x).

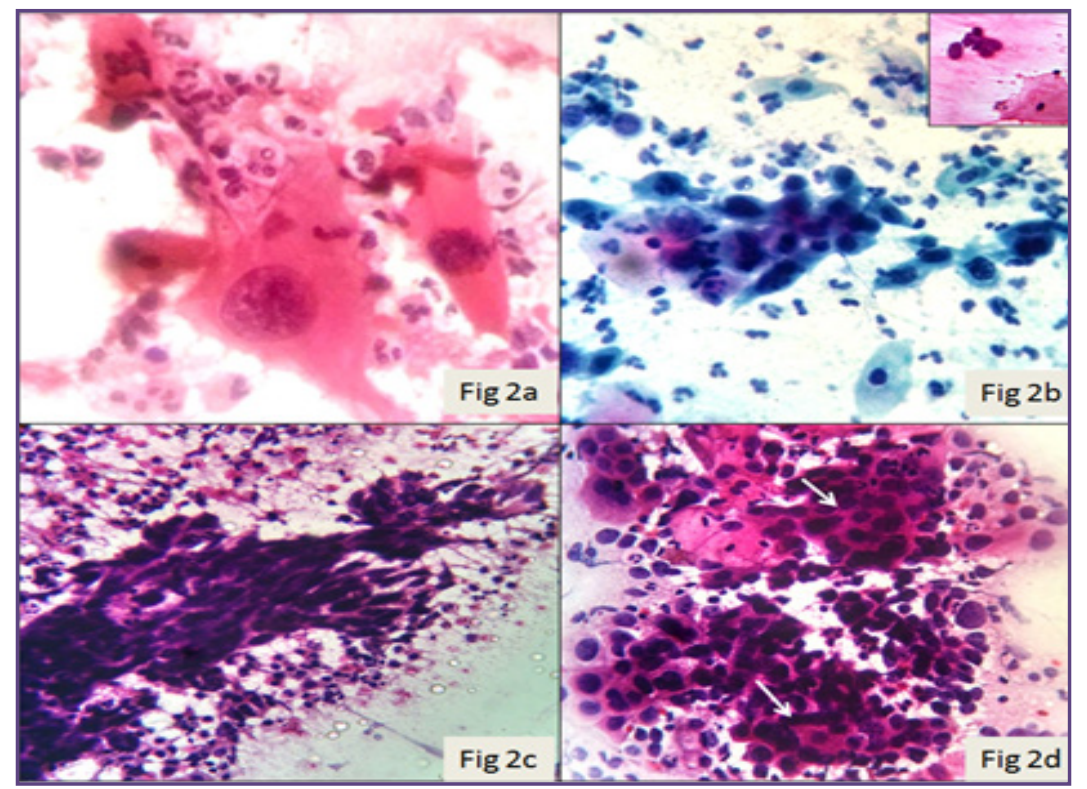

Fig. 2: Epithelial Cell Abnormalities - Fig 2a: LSIL. Fig 2b: HSIL.(Inset: Abnormal stripped nuclei seen on the same slide). Fig 2c: SCC. Fig 2d: Adenocarcinoma. (gland like configuration- white arrow). 


\section{Discussion}

Various conditions can affect uterine cervix, including non neoplastic \& neoplastic diseases at different age. The incidence of carcinoma cervix peaks at the age of 55 years in India. ${ }^{\left[{ }^{[9}\right.}$ It is preceded by premalignant lesions by approximately $10-20$ years. ${ }^{[9]}$ However, the infectious conditions are known to be more common in reproductive age group. All of these are found very well by Pap smears.

The recent studies in South India have found NILM inflammatory smears to be most common finding in Pap smears, in approximately $70-90 \%$ of cases (Table 3$)$. ${ }^{[10]}$. [12-14], [16-20] Present study is concordant with them. Only few found them to be less common, second only to NILM Normal smear. ${ }^{[1],},{ }^{[15]}$ The age wise distribution of these cases has been done less frequently than in the premalignant $\&$ malignant lesions. Those who have studied the same, found inflammatory smears most common in 30-40 age group, [12], [14], [15] one of them mentioning $20-40$ years as common affected group in cytology. ${ }^{[13]}$ Present study also finds NILM, Inflammatory smears to be common in Premenopausal women.

Most of these recent works found fungal infection morphologically consistent with Candida species as the most common organism associated with specific infection, ${ }^{[12-15], ~[17], ~[19] ~ f o l l o w e d ~ b y ~ B a c t e r i a l ~ V a g i n o s i s ~ i n ~}$ few, ${ }^{[1],},[16],[18]$ similar to the present work. Only a single work shows Trichomonas vaginalis as the most common organism. ${ }^{[10]}$

Chronic lymphocytic cervicitis (follicular cervicitis) is known to be more common and more likely to be detected in Postmenopausal women, ${ }^{[2]}$ complying finding seen in present work.

The national guideline for cervical cancer screening in India advocates screening of women between 30 years to 59 years of age. ${ }^{[9]}$ We found 7 of the 240 women $(2.92 \%)$ of $\geq 60$ years have Cervical Intraepithelial Neoplasia 2 (CIN2) or worse lesions, the rate which is almost 12.7 times that of $0.23 \%$ in $18-59$ years( 15 of 6407$)$. Sixty-four percent of the CIN 2 or worse lesions at ages over 50 years were detected in women with previously negative smears by Blanks RG et al ${ }^{[22]}$ In present study the overall epithelial abnormalities were also more common in $\geq 60$ years age group (12 of 240 cases $-5 \%$ ) against only $1.05 \%$ (67 of 6407) in the rest (Table 2). Thus, it is suggested that screening should be continued for women $\geq 60$ years of age as well, even if having a negative cytology history. Large scale studies of Pap smear aiming the same age group in different regions of the country should be preformed.
We found 11 cases of HSIL in premenopausal \& postmenopausal groups each, majority being $\geq 60$ years age and second most affected age group is 30-39 years (Table 2). Of the recent studies, maximum HSIL cases in 40- 50 years, ${ }^{[12],[15],[19]} \&$ in $\geq 50$ years were found in three each. ${ }^{[13],[14],[18]}$

Most of LSIL belonged to 40 - 49 years (perimenopausal age), concordant with two recent works:; ${ }^{[12],[14]}$ whereas maximum affected group of $50-60,{ }^{[13],[18]} \& 30-40$ was seen in two studies each (Table 6). ${ }^{[15],[19] \mathrm{s}}$

As mentioned by Bethesda, ASCUS was the most common epithelial abnormality reported here as well, with 50-59 years common age. However, most of the other studies found it to be maximum in $41-50$ years. ${ }^{[13],[15],[19]}$ Out of the remaining studies, one each have found maximum ASCUS cases in same age group(50-59 years), older ( $\geq 60$ years) ${ }^{[18]} \&$ younger $\left(30-40\right.$ years). ${ }^{[14]}$

The percentage of interpretation of SCC by PAP smears in South Indian studies in these two years is ranging from 0 to $1.8 \%$, present one has $0.14 \%$ (9 cases) lying within the range. The range of age in India having maximum cervical cancer incidence is $55-59$ years. ${ }^{[23]}$ Same finding is seen in the above mentioned studies, ${ }^{[12-13],[15],[18-19]}$ but in our work it was $4^{\text {th }}$ decade (perimenopausal age) with two cases younger than 35years. These younger cases constituted $22.22 \%$ of all SCC cases. Recently the proportion of younger women being affected by SCC is increasing worldwide, accounting for about $25 \%$ of all patients in the US. ${ }^{[24]}$ Adenocarcinoma of cervix is the least interpreted category in the studies in Table 3, though the incidence has been increasing world over, followed by AGUS \& ASC - H. Present work shows interpretation as AGUS - two cases, Adenocarcinoma \& ASC-H one case each. Symptoms of curdy discharge \& foul smelling thin white discharge per vaginum correlated well with Pap interpretation of Candidiasis \& Bacterial vaginosis respectively. Per speculum finding in five of nine cases of SCC cervix was ulcerative/ fungating growth, in rest of the cases history of post coital bleeding \& post menopausal bleeding was present in two each.

\section{Conclusion}

From this work it is suggested that the Pap screening should not be ceased, but continued beyond 60 years of age. In premenopausal age, along with SIL, identification of malignancy \& infection should also be paid more attention, so as to curb their mortality \& morbidity respectively. Thus, irrespective of the age of female after $30 \mathrm{yrs}$, it is highly recommended for them to undergo Pap screening with follow up whenever required. 


\section{Reference}

1. Poste P, Patil A, Andola S. Incidence of Non-Neoplastic Cervical Pathologies Recorded at a Medical College. IJRRAS. 2015; 2(2): 039-050.

2. Lowe DG. Caricnoma of the cervix with massive eosinophilia. BJOG. 1988; 95: 393-401.

3. Paavonen $\mathrm{J}$ et al. Etiology of cervical inflammation. Am $\mathrm{J}$ Obstet Gynecol. 1986; 154(3): 556-64.

4. Kerkar RA, Kulkarni YV. Screening for cervical cancer: An overview. J Obstet Gynecol India. 2006; 56: 115-22.

5. Wahi PN, Luthar UK, Mali S, Shimkin MB. Prevalence and distribution of cancer of the uterine cervix in Agra district, India. Cancer. 1972; 30: 720-725.

6. Abell M.R., Ramirez J.A. Sarcomas and carcinosarcomas of the uterine cervix. Cancer. 1973; 31: 1176- 1192.

7. Afrakhteh M, Khodakarami N, Moradi A, Alavi E, Shirazi FH. A study of 13315 papanicolaou smear diagnoses in Sohada hospital. J Fam Reprod Health. 2007; 1: 75-9.

8. Ahuja M. Age of menopause and determinants of menopause age: A PAN India survey by IMS. J Midlife Health. 2016; 7(3): 126-131.

9. ICMR. Consensus document of the management of cancer cervix. Prepared as an outcome of ICMR subcommittee on cervix cancer. 2016

10. Deepthi KN, Aravinda Macharla. Lesions of uterine cervix by cytology and histopathology- A prospective study for a period of two years. Indian Journal of Pathology and Oncology. 2017; 4(2): 193-198.

11. Shashidhar MR, Shikha Jayasheelan. Prevalence of cervical cancer and role of screening programmes by PAP smears. MedPulse International Journal of Pathology, 2017; 1(2): 32-36.

12. Pushpalatha K, Pramila GR, Sudhakar R. Comparative study of visual inspection with acetic acid (VIA), Pap smear and biopsy for cervical cytology. Indian Journal of Pathology and Oncology. 2017; 4(2): 232-236.

13. Sharadamani GS, Anusha N. Spectrum of Cervical Lesions Detected by Pap Smear: An Experience from a RuralBased Tertiary Care Teaching Hospital. Indian Journal of Pathology: Research and Practice. 2017; 6 (2)(2): 435-438.
14. Ali SS, Prabhu MH, Deoghare S, InamdarSS, Deepak N. Spectrum of Cervical Lesions by Papanicolaou (Pap) Smear Screening in Remote Area of Bagalkot- A Camp Approach. Int. J. Life. Sci. Scienti. Res. 2017; 3(3): 986-991.

15. Sujatha R, Archana, Saravanakumar N, Subramaniam PM. Study of cervical PAP smear at medical college hospital in a rural setup. Indian Journal of Obstetrics and Gynecology Research 2017; 4(2):189-192.

16. Umarani MK, Gayathri MN, MadhuKumar R. Study of cervical cytology in Papanicolaou (Pap) smears in a tertiary care hospital. Indian Journal of Pathology and Oncology, October-December 2016; 3(4); 679-683.

17. Sujatha P, Indira V, Kandukuri MK. Study of PAP smear examination in patients complaining of leucorrhoea - A 2 years prospective study in a teaching hospital. IAIM. 2016; 3(5): 106-112.

18. Geethu GN, Shamsuddin F, Narayanan T, Balan P. Cytopathological pattern of cervical pap smears - a study among population of North Malabar in Kerala. Indian Journal of Pathology and Oncology. 2016; 3(4); 552-557.

19. Chaithanya K, Kanabur DR, Parshwanath HA. Cytohistopathological Study of Cervical Lesions. International Journal of Scientific Study. 2016; 4(2): 137 140 .

20. Atla BL, Uma P, Shamili M., SatishKumar S. Cytological patterns of cervical pap smears with histopathological correlation. Int J Res Med Sci. 2015; 3(8): 1911-1916.

21. Roberts $\mathrm{TH}, \mathrm{Ng} \mathrm{AB}$. Chronic lymphocytic cervicitis: cytologic and histopathologic manifestations. Acta Cytol. 1975; 19(3): 235-43.

22. R G Blanks, S M Moss, S Addou, D A Coleman, and A J Swerdlow. Risk of cervical abnormality after age 50 in women with previously negative smears. Br J Cancer. 2009; 100(11): 1832-1836.

23. World - both sexes estimated incidence by age. [Accessed October 30, 2014]. Available from: http://www.globocan. iarc.fr/old/age_specific_table_r.asp?

24. Olga BI \& Michael RH. (2015) Ch 36 The Uterine Cervix. In Silverberg's Principles \& Practice of Surgical Pathology \& Cytopathology. 5th Edition. (pp. 2537-2592) Cambridge University Press.

*Corresponding author:

Vaishali Baburao Nagose, Department of Pathology, Mamata Medical College, Rotary Nagar, Khammam, Telangana, India, Pin

Phone: +91 8500571871

Email: vaishali.nagose@gmail.com

Financial or other Competing Interests: None.

Date of Submission : 25.08.2017

Date of Acceptance : 12.09.2017

Date of Publication : 22.12.2017 